In Memoriam

http://dx.doi.org/10.1590/S0104-71832020000100001

\title{
Sérgio Alves Teixeira (1932-2020)
}

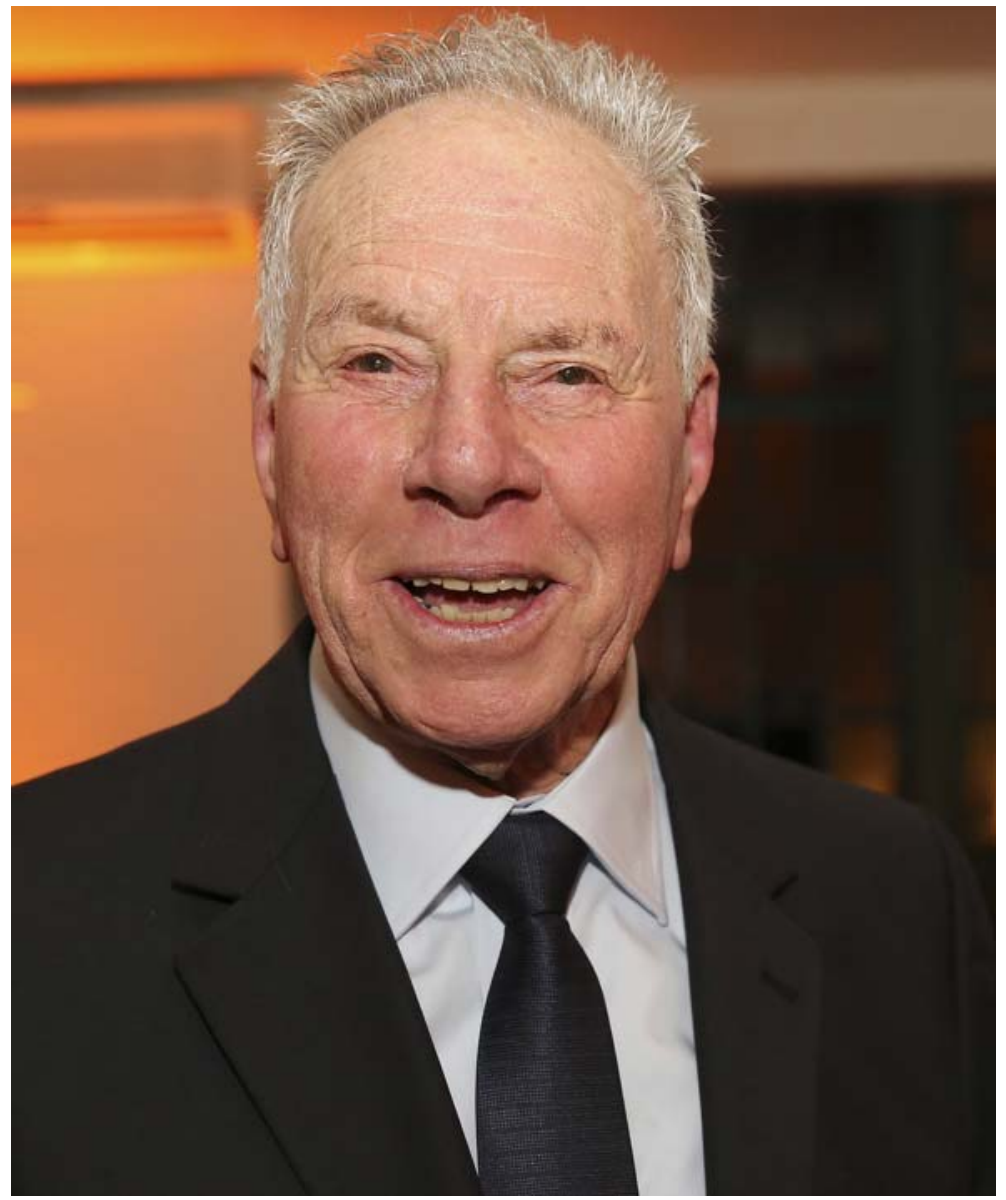

Foto: Carlos Jerônimo Ulrich Teixeira. 
É com imensa tristeza que comunicamos o falecimento de nosso colega Sérgio Alves Teixeira, ocorrido no dia 8 de fevereiro de 2020. Sérgio foi professor do Departamento de Antropologia da UFRGS durante mais de 30 anos e um dos fundadores de nosso programa de pós-graduação, que o teve como coordenador entre 1986 e 1990. Idealizador de nossa revista Horizontes Antropológicos, foi seu primeiro editor-chefe. Atualmente, era seu editor honorário. Ele também foi vice-diretor do Instituto de Filosofia e Ciências Humanas e coordenador da disciplina Introdução ao Estudo do Homem, ministrada a todos os alunos ingressantes na UFRGS em seu Ciclo Básico no começo da década de 1970.

Sérgio era licenciado em História pela UFRGS e mestre em Antropologia Social pela Unicamp. Ele foi um dos responsáveis na UFRGS pelo impulso à pesquisa antropológica de sociedades urbanas, tendo publicado artigos sobre rituais seculares e desvio social. Pioneiro no estudo de rituais no meio rural, realizou várias pesquisas e publicou artigos sobre o tema. Sua dissertação de mestrado intitula-se $O$ bordão do pobre: um estudo sobre o gado como estratégia econômica para uma população minifundiária do Rio Grande do Sul (Teixeira, 1976). Seu ensaio $O$ recado das festas: representações e poder no Brasil foi agraciado com o Prêmio Sílvio Romero concedido pela Funarte, que o publicou como livro (Teixeira, 1988). Trata-se de uma criativa pesquisa etnográfica sobre o significado das festas urbanas para produtos agrícolas no Brasil, com ênfase no Rio Grande do Sul.

A partir de 1985, Sérgio coordenou o projeto Capes-Cofecub entre o PPGAS-UFRGS e a Universidade de Paris V. Essa cooperação acadêmica foi responsável pela formação de docentes de nosso departamento e pela vinda de professores franceses para o Brasil. Um dos resultados desse intercâmbio foi o livro Brasil \& França: ensaios de antropologia social, organizado por ele e Ari Pedro Oro e publicado pela Editora da UFRGS em 1992 (Teixeira; Oro, 1992).

Sérgio era membro do Instituto Histórico e Geográfico do Rio Grande do Sul. De 1990 a 1992, ele fez parte da diretoria da Associação Brasileira de Antropologia. Em 1995, ele presidiu a Primeira Reunião de Antropologia do Mercosul, realizada em Tramandaí (RS), evento acadêmico que até agora já realizou 13 edições no Brasil e em outros países da América Latina. No último congresso, ele recebeu uma homenagem pública.

Em 1997, Horizontes Antropológicos em seu número 7 publicou um extenso depoimento sobre sua trajetória na UFRGS (Teixeira, 1997). 
Sérgio era uma pessoa afetiva e agregadora que fez da Antropologia sua segunda família. Ele acreditava no espírito de grupo, sempre estava disponível e tinha uma palavra de incentivo às pessoas que o rodeavam. Sua frase predileta era "Tudo pela Antropologia", o que mostra a sua dedicação pela área. Perdemos um grande amigo e colega que certamente será lembrado com carinho por todos aqueles que conviveram com ele. Seu legado faz parte de nossa história.

Ele deixa Carmen Maria, sua esposa e companheira de todas as horas, seus filhos Carlos Jerônimo e Aline, a nora Adriana e o neto Érico.

Ruben George Oliven

Editor-chefe

\section{Referências}

TEIXEIRA, S. A. O bordão do pobre: um estudo sobre o gado como estratégia econômica para uma população minifundiária do Rio Grande do Sul. 1976. Dissertação (Mestrado em Antropologia Social) - Instituto de Filosofia e Ciências Humanas, Universidade Estadual de Campinas, Campinas, 1976.

TEIXEIRA, S. A. O recado das festas: representações e poder no Brasil. Rio de Janeiro: Funarte, 1988.

TEIXEIRA, S. A. Depoimento sobre minha vivência na Antropologia da UFRGS. Horizontes Antropológicos, Porto Alegre, ano 3, n. 7, p. 276-314, nov. 1997. Disponível em: http://www.scielo.br/pdf/ha/v3n7/0104-7183-ha-3-7-0276.pdf. Acesso em: 18 fev. 2020.

TEIXEIRA, S. A.; ORO, A. P. (org.). Brasil \& França: ensaios de antropologia social. Porto Alegre: Editora da UFRGS, 1992.

* Universidade Federal do Rio Grande do Sul - Porto Alegre, RS, Brasil | ruben.oliven@gmail.com | https://orcid.org/0000-0003-3556-6955. 